\title{
ТРАНСФОРМАЦИЯ ОБЩЕСТВЕННОЙ СИСТЕМЫ РОССИИ В КОНТЕКСТЕ СОВРЕМЕННЫХ ВЫЗОВОВ
}

\author{
(C) 2019 Наумов Александр Сергеевич \\ кандидат экономических наук, старший научный сотрудник \\ Институт экономики РАН, Россия, Москва \\ E-mail: as.naumov@mail.ru
}

Анализируются этапы общественного развития, раскрываются их особенности, выделяются главные направления тех трансформационных процессов, которые осуществляются в различных сферах общественной жизни, рассматриваются пути выхода из идеологического и экономического кризиса.

Ключевые слова: общественное развитие, либерализм, кейнсианство, неолиберализм, доктрина, экономическая политика, государство, социальная среда, демократия, социальная структура общества, цифровая экономика, распределенное производство, ресурсы, ресурсная база, национальные проeкты.

Как известно, общественное развитие - это процесс, имеющий либо реформистский, либо революционный характер. На современном этапе он базируется на либеральной доктрине, которая, в свою очередь, опирается на три фундаментальных фактора: 1) частную собственность как основу экономической жизни; 2) свободное предпринимательство как главный фактор экономического прогресса; 3) свободную конкуренцию как регулирующий механизм экономических отношений, складывающихся между всеми субъектами рынка. При этом государству отводится роль регулятора общего равновесия экономики и экономического законодательства.

Экономическая доктрина либерализма, отвергающая необходимость широкого вмешательства государства в экономическую жизнь, и утверждающая, что наилучшей экономической системой является та, которая гарантирует свободу личной инициативы экономических субъектов, возникла в 18 веке (А. Смит). Она пережила свой расцвет в 19 веке (Дж. Ст. Милль, Ж.-Б. Сэй, Ф. Бастиа) в условиях промышленной революции и стала официальной доктриной стран, избравших путь капиталистического развития.

Разумеется, по мере этого развития либеральная доктрина претерпевала определенную трансформацию. Так, при переходе от эпохи свободной конкуренции к монополистическому капитализму усилилась роль государственного регулирования экономики. Теоретическое обоснование этой роли было дано английским экономистом Дж.М. Кейнсом. Он разработал це- лостную программу такого, регулирования. Ее основные положения изложены в работе «Общая теория занятости, процента и денег» (1936). При этом Кейнс не ограничился только теоретическим анализом наиболее актуальных проблем, но и выработал практические рекомендации по государственному регулированию капиталистической экономики. «Напомним, что эта программа базируется на следующих положениях: во-первых, капитализм, и в особенности система свободного рынка страдает врожденным пороками (инфляцией, безработицей, экономическими колебаниями) и не располагает механизмом, способным обеспечить экономическую стабильность и полную занятость; во-вторых, рыночная экономика не является самоорганизующейся системой, полная занятость здесь скорее случайна, чем закономерна; в-третьих, нельзя связывать колебания исключительно лишь с неблагоприятными внешними факторами (войны или форс-мажорные обстоятельства), напротив, они коренятся в значительной мере в отсутствии полной синхронизации в принятии различными субъектами основных экономических решений, касающихся, в частности, сбережений и инвестиций; в-четвертых, государство может и должно играть важную роль в регулировании экономики, ее стабилизации посредством проведения денежно-кредитной и бюджетноналоговой политик» [1].

Необходимо отметить также, что практическая программа Дж.М. Кейнса стала основой нового курса экономической политики Запада. 
Это выразилось, в частности, в развертывании процесса огосударствления экономики, создании новых рабочих мест, расширении рынков потребительских товаров и услуг, привлечении крупного бизнеса к выполнению государственных заказов, создании смешанных предприятий, разработку планов и программ социальноэкономического развития и т.д. Но в начале $70-\mathrm{x}$ годов прошлого века кейнсианская практика начала давать сбои из-за углубления нового экономического кризиса.

Именно поэтому против нее выступили неолибералы, ориентированные на либерализацию экономики, ведущую роль частной собственности. Вместе с тем, они признают необходимость ограниченного регулирования экономики государством в интересах обеспечения свободы конкуренции и предпринимательства. Поэтому их рекомендации в области экономической политики касаются главным образом ограничения и преодоления любых монополистических тенденций в экономике, широкого использования рыночных механизмов и т.д.

Эти рекомендации способствовали стабилизации капиталистической экономики, но не устранили присущих ей негативных явлений, которые обнаружились в конце 80-х начале 90-х гг. прошлого века По этой причине, надо полагать, экономическая политика развитых стран на современном этапе базируются на сочетании элементов неолиберальной модели с элементами неокейнсианской теории государственного регулирования экономики. Причем последние играют решающую роль в период острых социальноэкономических потрясений, о чем свидетельствуют мировой экономический кризис 20072009 годов.

Трансформации либерализма последних лет - эта попытка приспособиться к тем или иным вызовам современной экономики. Сказанное имеет непосредственное отношение и к современной России. Либеральная доктрина стала формироваться в ней после августовских событий 1990х гг. Суть ее заключается в том, что она ориентировалась на ускоренную, быструю капитализацию российской экономики посредством реализации политики «шоковой терапии». Последняя предполагала принципиальное разрушение государственно-централизованной системы хозяйствования с целью создания «чистой стартовой площадки» для ускоренного внедрения капиталистической рыночно- ориентированной экономики.

Как известно, основными элементами данной политики являлись: либерализация цен, приватизация и макроэкономическая стабилизация.

Но на практике она потерпела полный провал: российское общество действительно ощутило «шок без терапии». Это выразилось в разрушении развале экономического и оборонного потенциала страны, резком снижении уровня жизни населения, быстром обогащении нарождающейся российской буржуазии.

Не случайно исследователи обращают внимание на то, что изначально стратегический выбор на ускоренную капитализацию сам по себе является ошибочным. В этой связи Л.В. Никифоров пишет: «Существующие уровень и структура экономики, состояние внутренних хозяйственных связей, характеризующие степень экономической целостности страны не способны обеспечить как ее достаточную защищенность от внешних экономических вызовов и угроз, так и решение комплекса собственных проблем» [2].

В этой связи возникает необходимость учета, во-первых, новых явлений в экономике, которые в современных условиях базируются на знаниях, информации и новых технологиях; во-вторых, своеобразия российского варианта либеральных преобразований, суть которого на всем протяжении их истории и по сей день, заключается в том, что движение идет «сверху», а это не вызывало и не вызывает понимания у большинства населения России, которая не приемлет и отторгает их. Достаточно ознакомиться с социологическими исследованиями на эту тему, чтобы определить степень такого отторжения.

На наш взгляд, это происходит потому, что распространение либеральных взглядов не учитывает в полной мере исторические особенности и тенденции развития российского общества, Между тем только адекватное понимание этого обстоятельства позволяет определить наиболее эффективный путь эволюционного перехода к новому типу общественного развития, отвечающего интересам всех социальных групп.

Уместно напомнить, в этой связи выступление П.А. Столыпина с трибуны государственной Думы в начале прошлого века: «Я хочу еще сказать, что все те реформы, все то, что только что правительство предложило вашему вниманию, ведь это не сочинено, мы ничего насильственно, механистически не хотим внедрять в народное 
самосознание, все это глубоко национально... Ведь сословия и те не брали пример с Запада...» [3].

В этой связи резко возрастает роль таких системообразующих элементов российского общества, как научно-образовательные и культурноисторические институты, которые должны быть направлены и на сохранение своих идентификационных элементов, и на формирование понимания населением сути процессов рыночных отношений; здесь имеются в виду, как построение гражданского общества, так и «сферы, не поддающиеся рыночному воздействию,- охрана окружающей среды, фундаментальная наука и культура, национальные заповедники, а также сфера прав человека и нравственность!» [4,C. 14-19].

Иными словами, достичь стабильного развития общества возможно только при основе органического взаимодействия демографического, финансового, экономического, транспортного, научно-образовательного и культурноисторического потенциала страны, что является обязательным условием структурной модернизации российской экономики. Такая модернизация должна использовать долговременные составляющие развития, ориентирующихся на состояние мировой экономики и с учетом глобальных трансформаций, происходящих в ней.

Но вместо синтеза интересов различных слоев российского общества, направленного на социально-экономическую трансформацию, российская бюрократия, в новом для себя порядке вещей, создает запутанный формализованный лабиринт взаимоотношений народа и элиты. Тем самым происходит одностороннее «развитие интересов». В таком государстве «государственные интересы» (а это обычно интересы конкретных лиц, находящихся у власти), начинают именоваться «национальными», и превалируют над общественными.

Есть ли выход? На этот вопрос весьма доходчиво отвечает Л.В. Никифоров. В частности, он пишет: «Несмотря на негативные тенденции в нашей стране еще не утрачены определенные предпосылки развития современных тенденций общественной трансформации, но для их сохранения и реализации необходимо устранить основы тех аспектов перемен, которые являются исторически попятными» [5].

Следует отметить, что ни научные наработки, ни практические результаты, ни обращение к истории не изменили взгляды российских либералов: они не спешат переходить от политических деклараций к реальным действиям.

Суть проблемы заключается в следующем: реформы продолжают осуществляться в условиях сохранения существующей олигархической политической системы. Ибо важнейшей целью реализации реформ является сохранение этой системы, посредством ее постепенной модернизации и вписывания в меняющуюся социальную среду, что обуславливает тормозящий эффект. Половинчатые экономические, политические и социальные реформы характерны для подобных реформ. «Опыт отнюдь не доказывает, что инвестиционная политика, приносящая пользу с социальной точки зрения, приносит одновременно и наибольшую прибыль. Чтобы побороть силы времени и наше невежество, требуется больше ума, чем для того, чтобы «опередить пулю» [6].

В этом процессе оптимальным представляется сочетание зарубежного политического опыта с историческим опытом России. И дело здесь не столько в выборе, сколько в осознании приемлемости такого выбора, понимании того, насколько успешно этот выбор повлияет на формирование социального государства, которое возможно лишь при наличии социально направленной экономики. В некоторых европейских конституциях прямо записано: «Все виды богатства страны в своих различных формах, независимо от собственника, служат общим интересам». В современной России отсутствует даже консенсус главных политических сил по этим ключевым вопросам.

«Русских невозможно победить, мы убедились в этом за сотни лет. Но русским можно привить лживые ценности и тогда они победят сами себя»,- писал Отто Бисмарк по этому поводу. Приведем лишь некоторые «ценности», а именно: во-первых, лишение народа среды привычного обитания, и как следствие - демографические проблемы: разрушение села, рост количества городских агломераций; во-вторых, искажение ресурсной базы образования, здравоохранения, науки, и как следствие - отток квалифицированных работников за рубеж, не принимающих по существу эти «ценности».

Профессор Народного университета имени Мао Цзэдуна и член-корреспондент Академии наук КНР Цзинь Сычжан, выступая перед студентами МГТУ им. Баумана на конференции 
«Современные проблемы науки и образования», назвал единый государственный экзамен «главной угрозой развитию технологий в России» и «величайшей диверсией Запада», прямо указывая на деградацию выпускников. По словам Цзинь Сычжана «в России падение качества образования за последние 10 лет составило более 61\%. За аналогичный период в китайских школах, где ЕГЭ введён не был, этот показатель повысился на 39\%.» [8].

Кроме того, современная Россия утратила присущие ей идеологические ориентиры, как православие XIX века и коммунизм XX века, а новые пока не сформулированы. Именно поэтому важнейшую роль в подъеме страны должна сыграть ее национальная элита. Не сделать ли национальной идеей реализацию прав человека? Ведь политическое равенство и экономическое благополучие - базовые понятия развитого гражданского общества, члены которого все равны перед законом, какой бы национальности они не были, какую бы веру не исповедовали, какое бы социальное положение не занимали.

Становится очевидным тот факт, что нынешняя политическая и экономическая элита не способна к модернизации России, если ее понимать, как ускоренную реализацию системных мер по преобразованию всей системы общественных отношений. «Президент свободной республики Рузвельт заявил прямо и открыто: американский гражданин только тот, кто всей душой предан Америке. Почему в России должны думать иначе!» [9].

Здесь, при выработке стратегии развития России, особая роль принадлежит научному сообществу, способному, на наш взгляд, связать общемировые тенденции развития с историческими особенностями России и нащупать путь, позволивший бы органично вписаться в мировые глобализационные процессы.

В этом контексте ключевая роль принадлежит цифровой экономике, она уже начинает определять новые задачи и цели, а именно: «обеспечение высокого качества конечных услуг или товаров с наименьшей стоимостью в любых количествах, как больших, так и малых; широкая кастомизация продуктов при условии гибкого производства; внедрение методов самостоятельной оптимизации, самонастройки и самодиагностики. Некоторые крупные компании ФРГ уже сегодня готовятся к тяжелейшим экономи- ческим кризисам и к торгово-тарифным войнам 21 века» [10].

Экономисты предполагают, что мировая экономика постепенно превращается в «глобально распределенную сетевую фабрику (factory world) [Los et al., 2015; Santoni, Taglioni, 2015]. Такую фабрику можно представить как многомерное сетевое пространство с распределенными механизмами координации, где каждый торгуемый продукт создается на проектной основе независимыми компаниями нескольких стран, генерируя свой поток добавленной стоимости, и где в местах пересечения таких потоков формируются мощные страновые и макрорегиональные узлы наращивания глобальной производительности» [11. С. 87].

При распространении такого подхода исчезнут традиционные рынки труда. Возможности производства будут эволюционировать и приспосабливаться к рынкам и географическим особенностям. Так, практически во все отдаленные и труднодоступные территории получат доступ к широкому спектру цивилизационных благ, что для российского государства является крайне важным обстоятельством.

Здесь просматривается главная социальноэкономическая проблема, которую придется решать в недалеком будущем, а именно, создание механизмов и современной ресурсной базы для обеспечения достижения национальных целей опережающего развития. С этой точки зрения национальные проекты могут рассматриваться, как один из способов формирования ресурсной базы нового поколения.

Именно здесь, по нашему мнению, находится точка пересечения развитых экономических отношений и социума, готового их поддержать и совершить цивилизационный скачок в шестой промышленный уклад Однако это, с неизбежностью, приведет к распаду существующей социальной структуры общества и возникновению совершенно новой, где не будет места диктату чиновничества, исчезнет коррупционная составляющая и незаконное обогащение в силу своей невозможности. Осмысление этих процессов сейчас поможет облегчить путь социальноэкономического развития в этом направлении и позволит избежать будущих непреодолимых, с точки зрения сегодняшнего положения дел, социальных противоречий. 


\section{Библиографический список}

1. Сычев Н.В. Очерки истории экономических учений. М., гУУ. 1998. С. 58-59.

2. Никифоров Л.В. Поворот стратегии социально-экономического развития России.- М., ИЭ РАН. 2010. С. 3-4.

3. Столыпин П.А. Полное собрание речей в Государственной Думе и Государственном Совете 1906-1911.- М.: Молодая гвардия.-1991.- С. 106.

4. Абалкин Л. Вызовы нового века. М., 2001, С. 14.

5. Никифоров Л.В. Отношения собственности: тенденции трансформации.- М.: ИЭ РАН, 2001.-С. 73.

6. Кейнс Дж. М. Общая теория занятости, процента и денег. М., Прогресс. 1978. С. 74.

7. Parsons T. The Concept of Society: The Components and Their.- Prentice-Нall, Перевод к.ф.н. Н. Поляковой, 1966. - C. 5-29.

8. http://asiarussia.ru/news/21484/.

9. овалевский П.И. Национализм и национальное воспитание в России. Издание союза «Единство Руси, Нью Йорк 1922. С. 14.

10. Ситников А. Промышленная Россия 4.0: перед лицом краха 30 технологий и технических достижений, без которых нас ждет участь несчастной Ливии. [Электронный ресурс]. 14.12.2017.-Режим доступа: https://svpressa.ru/economy/article/187584/._- Дата доступа: 04.10.2018.

11. https://inecon.org/docs/Smorodinskaya_Katukov_EP_2017.pdf. C. 87. 